\title{
The making of the Court's homosexual: a queer reading of the European Court of Human Rights' case law on same-sex sexuality
}

Damian A Gonzalez-SalzberG*

University of Sheffield, School of Law

\section{Introduction}

$\mathrm{T}$ The presence of same-sex sexuality before a court of law is far from being a novelty but its understanding as a personal characteristic worthy of legal protection has a very short history indeed. An important moment of this new tradition occurred in 1981 when the European Court of Human Rights (the Court) decided the Dudgeon case. On this occasion the Court ruled that the criminalisation of same-sex sexuality in private was a violation of the right to respect for private life, protected by the European Convention on Human Rights (the Convention). ${ }^{1}$ The Court has since become the leading international judicial body dealing with the recognition of sexual orientation as a relevant topic of human rights law.

The Court's developing case law on same-sex sexuality has been thoroughly studied by many authors. From a traditional liberal perspective, the works of Harris and Wintemute have highlighted the importance of the case law of the Court. ${ }^{2}$ More recent analyses conducted by Grigolo and Johnson have ventured to critically evaluate the Court's case law using a constructionist theoretical approach, focusing on the discursive power of the jurisprudence. ${ }^{3}$ Nonetheless, queer theory as a methodological tool for analysing the legal discourse of the Court has rarely been used. ${ }^{4}$ This article seeks to rectify that gap in the literature.

* Lecturer in law, University of Sheffield d.a.gonzalez-salzberg@sheffield.ac.uk. My thanks go to Professor Carl F Stychin, Dr Aleardo Zanghellini and Dr Michele Grigolo for their comments on previous drafts of this article. I would also like to thank the anonymous reviewer for their very helpful suggestions.

1 Dudgeon v UK App no 7525/76 4 EHRR 149.

2 D J Harris, M O'Boyle, C Warbrick and E Bates, Law of the European Convention on Human Rights (OUP 2009); R Wintemute, Sexual Orientation and Human Rights: The United States Constitution, the European Convention, and the Canadian Charter (Clarendon Press 1997); R Wintemute, "From "Sex Rights" to "Love Rights": Partnership Rights as Human Rights' in N Bamforth (ed), Sex Rights: The Oxford Amnesty Lectures 2002 (OUP 2005) 186-224.

3 M Grigolo, 'Sexualities and the ECHR: Introducing the Universal Sexual Legal Subject' (2003) 14(5) European Journal of International Law 1023-44; P Johnson, 'An Essentially Private Manifestation of Human Personality: Constructions of Homosexuality in the European Court of Human Rights' (2010) 10(1) Human Rights Law Review 67-97; P Johnson, Homosexuality and the European Court of Human Rights (Routledge 2013).

4 The works of Wayne Morgan and Michele Grigolo appear as the rare exceptions to the lack of queer analysis of the Court's case law: W Morgan, 'Queering International Human Rights Law' in C Stychin and D Herman (eds), Sexuality in the Legal Arena (Athlone Press 2000) 208-25; Grigolo (n 3). 
Queer theory adopts a post-structuralist understanding of identities that contest their stability, challenging not only the fixity of categories such as sex, gender and sexuality, but also the traditional construction of these characteristics as opposed binaries. ${ }^{5}$ Working within this framework, the article will perform a deconstructive reading of 40 rulings on same-sex sexuality issued by the Court during three decades, from the Dudgeon case in 1981 to the $X$ and Others case in 2013. The aim of the analysis is to illustrate how the Court's case law has discursively created the Court's homosexual. In particular, the use of queer theory will highlight the impact of the regulatory power of human rights law on the performative character of sexual identities. ${ }^{6}$ The analysis will certainly not exhaust the potential of queerly thinking human rights law, but it will draw attention to the relevance of queer theory for the analysis of the Court's homosexual past and future.

Following Butler, it can be understood that intelligible subjects are created through an exclusionary process that has, as a logical need, the simultaneous creation of the non-subject, the 'Other'. 7 The construction of the Court's homosexual has been no exception. It has been shaped within the Court's case law as the opposite counterpart of the true subject of human rights law, the heterosexual, the only one entitled to the full enjoyment of human rights.

Within three decades of rulings, the Court has not offered a legal definition of homosexuality. Instead, the Court has been exercising the authority of the law, constituting and regulating the legal meaning of sexual identities. ${ }^{8}$ It is through the Court's case law that the Court's homosexual has been created, acquiring the characteristics granted to him/her by the Court.

The analysis of the rulings dealing with same-sex sexuality will be conducted by resorting to seven deconstructive binaries that have been present - either implicitly or explicitly - in the Court's case law. ${ }^{9}$ The seven dichotomies to be used in the deconstruction of the judgments are: heterosexual/homosexual; legal/illegal; inside/out; private/public; equal/different; couple/uncouple; and self/other. Even though just a few of these binaries explicitly recognise the lesser value of one of the terms involved, they all share this characteristic. As clearly expressed by Sedgwick, many seemingly symmetrical binary oppositions actually subsist in a dynamic relation according to which one of the terms is nothing but subordinated to the other. In fact, the true meaning of the two terms can only be understood by their tacit hierarchical interrelation. ${ }^{10}$

In brief, the article will engage in a queer analysis of the rulings on same-sex sexuality issued by the Court between 1981 and 2013 in order to illustrate the creation process of the Court's homosexual. Section 2 of the article will offer a theoretical understanding of the categorical approach the Court has adopted for conceiving the legal sexuality of individuals. Section 3 will present the analysis of 24 judgments of the Court through three binary pairs. It will focus on how the protection the Court has offered to its homosexual has shifted

5 A Jagose, Queer Theory (Melbourne University Press 1996) 3; C Stychin, Law's Desire: Sexuality and the Limits of Justice (Routledge 1995) 141; J Weeks, The Language of Sexuality (Routledge 2011) 146.

6 Morgan (n 4) 217-18; A Zanghellini, 'Queer, Antinormativity, Counter-normativity and Abjection' (2009) 18(1) Griffith Law Review 1-16, 6.

7 J Butler, Bodies that Matter (e-book Taylor \& Francis 2011) xiii.

8 Stychin (n 5) 156; N Beger, 'Queer Readings of Europe: Gender Identity, Sexual Orientation and the (Im)potency of Rights Politics at the European Court of Justice' (2000) 9(2) Social and Legal Studies 249-70, 264.

9 For the use of deconstructive binaries as a methodological tool, see: E Kosofsky Sedgwick, Epistemology of the Closet (University of California Press 1990) 9-11; C Stychin, 'Couplings: Civil Partnership in the United Kingdom' (2005) 8 New York City Law Review 543-72.

10 Sedgwick (n 9) 9-10. 
through the years, allowing his/her journey from the privacy of the closet to the public sphere. Section 4 will resort to two binary oppositions in order to analyse the remaining 16 rulings of the Court. It will show how the Court's case law has used both the concession and denial of human rights to create its homosexual as the inferior counterpart of the heterosexual subject. Section 5 will summarise the main findings of the analysis performed and propose a potential way forward.

\section{The categorical approach to homosexuality (heterosexual/homosexual)}

An essential departing point of a queer analysis is the heterosexual/homosexual binary which represents the existence of human sexuality as only two compulsory and contradictory options. Queer theory has shown the peculiar nature of this binary, since its first term is presented as the category to which everyone is supposed to belong; while the belonging to the second group only takes place as an exclusion, by the inability of the subject to fit into the first one. ${ }^{11}$ Therefore, even though the Court's homosexual is supposedly presented as the stable counterpart of the heterosexual subject, ${ }^{12}$ his/her legal existence is marked from the outset by the impossibility of fitting into the right(ful) side of the binary.

Furthermore, the binary division of sexual identity not only consolidates heterosexuality as the background norm, since the two options offered are not of the same value, but also restricts the diversity of sexuality. ${ }^{13}$ In fact, the Court has assumed that every single individual could be perfectly fitted into one (and only one) side of the binary. Other possible options have appeared in the Court's case law only in a tangential way and have never been a part of the holding of a decision.

For example, the term 'bisexual' has sporadically appeared in the rulings of the Court, but only when quoting fragments of domestic decisions or international soft law instruments; ${ }^{14}$ and an undefined reference to 'pansexual' individuals appeared in the partially dissenting vote of Judge Walsh in the Dudgeon case itself. ${ }^{15}$ It was not until the year 2010 that the Court showed a degree of willingness to open the binary, when it made reference to gays, lesbians and any other sexual minority. ${ }^{16}$ Nonetheless, this simple reference has not had any legal consequences in the Court's case law so far.

On the other hand, it seems to be mandatory for every individual before the Court to have a sexual orientation and, therefore, to take a place on one of the sides of the binary. The Court has implicitly answered in the affirmative the appealing question posed by Gross: does each person have a sexual orientation? ${ }^{17}$ Indeed, the complete absence of any reference to 'asexuality' within the Court's case law helps in proving the belief in sexual orientation as a compulsory personal characteristic.

The fact that sexual orientation is mandatory, coupled with the existence of only two possible options, ensures that every single individual is placed on one of the sides of the heterosexual/homosexual binary. This categorical approach delineates a restrictive

11 D Halperin, Saint Foucault: Towards a Gay Hagiograpby (OUP 1997) 44.

12 Grigolo (n 3) 1030.

13 L C Backer, 'Queering Theory: An Essay on the Conceit of Revolution in Law' in L Moran, D Monk and S Beresford (eds), Legal Queeries: Lesbian, Gay and Transgender Legal Studies (Cassell 1998) 188.

14 Schererv Switzerland (Case 19/1993/414/493) ECHR 23 March 1994, para 11; Laskey and Others v UK App nos 21627/93; 21628/93; 21974/93 24 EHRR 39, paras 11 and 47; TN v Denmark. App no 36517/08 (ECHR 20 January 2011), para 65; EG v UK App no 41178/08 (ECHR 28 November 2011), para 45.

15 Dudgeon $v$ UK (n 1), dissenting opinion of Judge Walsh.

16 Alekseyev v Russia App nos 4916/07; 25924/08; 4599/09 (ECHR 21 October 2010), para 84.

17 A Gross, 'Queer Theory and International Human Rights Law: Does Each Person have a Sexual Orientation?’ (2007) 101 American Society of International Law and Procedure 129-32. 
conception of human sexuality within the Court's case law, acting as a clear display of the regulatory power of the law over the Court's homosexual. The adoption of a categorical approach has allowed the Court to regulate, contain and constrain the legal sexuality of its homosexual. ${ }^{18}$ In particular, this limited conception of sexuality provided a clear departing point for the construction of the Court's homosexual as the private and inferior counterpart of the heterosexual subject, as will be discussed in sections 3 and 4 of this article.

\section{From the private closet to the public streets}

The following three binaries are aimed at deconstructing the developing protection that the Court has offered its homosexual through time. In particular, the analysis will show the 30year journey of the Court's homosexual from the secrecy of the closet to the public sphere. The binaries will illustrate the Court's reactions to the swinging tempers of governments that, at different times, have forced the Court's homosexual into secrecy; pushed him/her out of the closet; and censored him/her on the streets.

\section{A. LeGAL/ILLEGAL}

In almost half the cases concerning the Court's homosexual, the question to be answered was whether same-sex sexuality was to be considered criminal or lawful by the states. The first three cases introducing the Court's homosexual were Dudgeon, Norris and Modinos. In each of these cases the Court ruled that the mere existence of legislation criminalising private sexual activity between adult men was a violation of the Convention. ${ }^{19}$ Similarly, the later ruling in the $A D T$ case affirmed that legislation criminalising consensual sexual acts between more than two adult men was also a violation of the right to respect for private life. ${ }^{20}$

Therefore, the Court decided that its homosexual was entitled to a private sphere protected from the unjustified intrusions of the state. In particular, the Court's homosexual had the right to engage in same-sex acts, as long as those were performed by consenting adults in the secrecy of their home. Nonetheless, the protection granted to its homosexual was only a bare minimum, since the Court specifically stated in the Dudgeon case that decriminalisation did not imply approval. ${ }^{21}$ This unnecessary comment, made in the context of the case, can only be understood as either condoning a negative view of same-sex sexuality by the community, or as actually expressing the Court's rejection of its homosexual.

Furthermore, for over a decade after Dudgeon, the legality of same-sex sexuality was still contentious. Even if it could not be completely made illegal by the state, the Court did not venture further than recognising a limited private legality. In fact, the Court has been criticised for failing to recognise a needed difference between privacy and secrecy. ${ }^{22}$ The legality of same-sex sexuality seemed to have depended on its secrecy and, therefore, it was never truly lawful, but just kept unknown with the grace of the authorities.

18 C Stychin, 'Essential Rights and Contested Identities: Sexual Orientation and Equality Rights Jurisprudence in Canada' (1995) 8 Canadian Journal of Law and Jurisprudence 49-66, 56; L Gotell, 'Queering Law: Not by Vriend' (2002) 17(1) Canadian Journal of Law and Jurisprudence 89-113, 108.

19 Dudgeon v UK (n 1) para 63; Norris v Ireland App no 10581/83 13 EHRR 186, para 47; Modinos v Cyprus App no 15070/89 16 EHRR 485, para 26.

20 ADT v UK App 35765/97 31 EHRR 33, paras 38-39. At the same time, the Court recognised the ability of the government to regulate sexual acts in certain circumstances, in which looked like an implicit confirmation of its ruling on the Laskey case admitting the criminalisation of sado-masochistic practices for the alleged protection of health: Laskey and Others $v$ UK (n 14) para 50.

21 Dudgeon v UK (n 1) para 61.

22 Johnson, 'An Essentially Private Manifestation of Human Personality' (n 3) 86-7. 
The legal/illegal dilemma subsists at a certain level in the F case, decided by the Court in 2004. The Court decided that the prohibition on criminalising same-sex sexuality did not forbid extraditions to countries where the extradited person risked facing draconian punishments for his/her sexual orientation, at least when a judicial conviction was unlikely to take place. ${ }^{23}$ Consequently, the scope of the territorial jurisdiction of the Court also acted as the limit between legal and illegal sexuality. When the border of the Court's jurisdiction is crossed, the line that separates legality from illegality could also be erased, without worrying the Court.

The Court shaped its homosexual through the legal/illegal dichotomy in a second group of judgments, which dealt with a differential age of consent for same-sex and for differentsex sexuality. The Court decided eight similar cases against the UK and Austria ${ }^{24}$ and ruled that the domestic legislation that established a differential age of consent was discriminatory. ${ }^{25}$ The judgments stated that very weighty reasons needed to be offered in order to justify a differential age of consent between same-sex and different-sex sexuality, but such a justification did not exist in these cases. Consequently, the relevant age for sexual consent was to be equal for the heterosexual subject and the Court's homosexual. In this specific area, same-sex sexuality managed to acquire the same degree of legality as the sexuality of the heterosexual.

Moreover, that finding was not modified by the contentious Santos Couto case. The Court had to analyse a conviction for 'homosexual' acts with adolescents imposed by a Portuguese tribunal at a time when the legislation established different criteria for the criminalisation of same-sex and different-sex acts with minors. The Court did not find a violation because it understood that the conviction had not been influenced by the difference in the legislation concerning same-sex and different-sex sexuality. ${ }^{26}$ Therefore, the Santos Couto case did not change the lawful status acquired by the sexuality of the Court's homosexual since the ruling did not authorise the criminalisation of same-sex sexuality in circumstances in which different-sex sexuality remained lawful.

To summarise, the Court granted its homosexual protection from criminal prosecution, letting him/her rest on the safe side of the legal/illegal binary, as long as his/her sexuality remained a private matter. However, there subsists a specific situation in which the Court's homosexual might cross to the illegal side of the dichotomy: extradition outside the jurisdiction of the Court.

\section{B. INSIDE/OUT}

This particular binary could be seen as the original deconstructive dichotomy, since every opposite pair emulates the inside or outside dynamic. ${ }^{27}$ Nonetheless, within queer theory, this binary is peculiar, since the hierarchy of the terms is highly unstable. While 'out' is

23 F v UK App no 17341/03 (ECHR 22 June 2004), para 10.

24 There had been a previous case before them (the Sutherland case), but the Court did not take the opportunity to analyse the merits of the case since the parties reached a friendly settlement: Sutherland $v$ UK App no 25186/94 (ECHR [GC] 27 March 2001), para 20.

25 L and $V v$ Austria App nos 39392/98; 39829/98 36 EHRR 55; SL v Austria App no 45330/99 (ECHR 9 January 2003); BB v UK App no 53760/00 39 EHRR 30; Woditschke and Wilfling v Austria App nos 69756/01; 6306/02 41 EHRR 32; Ladner v Austria App no 18297/03 (ECHR 3 February 2005); Wolfmeyer v Austria App no 5263/03 42 EHRR 3; HG and GB v Austria App nos 11084/02; 15306/02 (ECHR 2 June 2005); RH $v$ Austria App no 7336/03 (ECHR 19 January 2006).

26 Santos Couto v Portugal App no 31874/07 (ECHR 21 September 2010), paras 44-5.

27 D Fuss (ed), Inside/Out: Lesbian Theories, Gay Theories (Routledge, 1991) 1. 
naturally subordinated for being the excluded term, it is revaluated, at the same time, for representing the successful abandonment of the closet. ${ }^{28}$

While the limited private legality of same-sex sexuality has already been stated, this binary will help develop what has happened to the Court's homosexual when he or she has dared step out of the closet, even if not voluntarily. Between 1999 and 2009, the Court decided a group of six cases in which coming out of the closet was also the cause of being driven out of the military. ${ }^{29}$

In two original twin cases the Court analysed the UK's policy of purely heterosexual armed forces, which included intrusive investigations into those suspected of 'homosexuality' and the consequent discharge of every individual identified as homosexual. The UK's policy had the paradoxical effect of forcing members of the armed forces both inside and outside the closet. If originally the 'homosexual ban' silenced the homosexual, locking him or her inside the closet; simultaneously, it forced the homosexual to come out, through invasive investigations into the constructed closet. The sexuality of the homosexual was, at the same time, forced into self-censorship and disclosure.

The Court decided that both the homosexual ban policy and the investigations pursued to establish the sexuality of those discharged were violations of the right to respect for their private lives. ${ }^{30}$ The Court understood that there were no convincing reasons for supporting the exclusion of its homosexual from the armed forces and that the manner in which the investigations were conducted was an unjustifiable interference into his/her private life.

In the eyes of the Court, being outside of the closet should not mean being outside the military and it certainly did not mean being outside the protection of the Convention. This judgment was reiterated in the analogous Beck and Perkins cases ${ }^{31}$ and was the rationale for reaching friendly settlements in the Brown and Hunt and Miller cases ${ }^{32}$ after the Ministry of Defence abandoned its contentious policy in the year 2000.

Since the military cases, the Court's homosexual became a less secret subject under the law. These cases were the first ones that granted a protection of same-sex sexuality outside the closet. The given protection was not public yet, as it was still granted through the right to respect for private life, but it took place beyond the limits of the private home.

\section{Private/Public}

The majority of the Court's rulings dealing with same-sex sexuality have been decided from a perspective centred on the right to respect for private life. The Court tended to base these decisions on the understanding that sexuality is an important part of an individual's private life. ${ }^{33}$ In fact, the Court's homosexual has been constructed as a private subject and that privacy has been the reason behind the protection granted by the Court. ${ }^{34}$

28 Fuss (n 27) 4.

29 This type of military policy was certainly not unique to the UK, but mirrored previous policies of other countries. Stychin (n 5) 91-100.

30 Lustig-Prean and Beckett v UK App nos 31417/96; 32377/96 29 EHRR 548, paras 64, 104 and 105; Smith and Grady v UK App nos 33985/96; 3986/96 29 EHRR 493, paras 71, 111 and 112.

31 Beck, Copp and Bazeley v UK App nos 48535/99; 48536/99; 48537/99 (ECHR 22 October 2002).

32 Brown v UK App no 52770/99 (ECHR 29 July 2003), paras 13-14; Hunt and Miller v UK App nos 10578/05; 10605/05 (ECHR 23 June 2009), paras 15-16.

33 Dudgeon v UK (n 1) para 60; ADT v UK (n 20) para 25; S and Marper v UK App nos 30562/04; 30566/04 (ECHR [GC] 4 December 2008), para 66; Axel Springer AG v Germany App no 39954/08 (ECHR [GC] 7 February 2012), para 83.

34 Johnson, 'An Essentially Private Manifestation of Human Personality' (n 3) 93, 94 and 97. In particular, Johnson highlights that the refusal to consider a violation of the right to freedom of expression in the Smith and Grady case (n 30) reinforced the private character the Court grants to homosexuality. 
However, obtaining recognition through privacy is a limited strategy, since it silences the actual existence of sexual diversity. 35 The private/public division is the manner in which Western law accommodates certain conducts that are neither prohibited nor truly accepted, but that can be tolerated if secluded to the private sphere. ${ }^{36}$ Certainly, the prohibition on the criminalisation of same-sex sexuality in private still allows the law to disapprove of the tolerated private conduct. ${ }^{37}$

Conversely, allowing same-sex sexuality to appear in the public sphere implies its official recognition by the law, as its existence can no longer be ignored. 38 Therefore, the private/public character of same-sex sexuality is a decisive issue since, when same-sex sexuality becomes a matter of public knowledge, the homosexual cannot be locked back into the closet.

It was not until the years 2007 and 2010 that the Court allowed same-sex sexuality to step out of the privacy closet into the public sphere. On those occasions, the Court dealt with governmental bans imposed on marches organised to draw public attention to discrimination based on sexual orientation, which took place in the capital cities of Poland and Russia. ${ }^{39}$ In both cases the Court found a violation of the right to assembly, coupled with the prohibition of discrimination based on sexual orientation. ${ }^{40}$ The Court understood that the authorities' refusal to allow the events was an unjustified interference with the right to peaceful assembly. ${ }^{41}$ Furthermore, the fact that the refused authorisations were linked to strong opinions against same-sex sexuality of the mayors of the cities allowed the Court to find the bans discriminatory in character. ${ }^{42}$

In the Baczkowski case, the Court actually recognised that sexual orientation was not just a matter of privacy, but that the right to publicly express one's sexual orientation was also protected by the Convention. ${ }^{43}$ This point was made even clearer in the Alekseyev case, in which the Court reaffirmed the right of individuals to openly identify themselves as gays and lesbians. ${ }^{44}$

Moreover, the Court has recognised certain protection for its homosexual in the public sphere since it has recently affirmed that freedom of expression does not include the liberty to resort to homophobic hate speech. ${ }^{45}$ In the Vejdeland case, the Court had to evaluate whether a conviction imposed by a Swedish tribunal for homophobic speech was compatible with the right to freedom of expression. The Court decided that the distribution of leaflets stating that homosexuality was 'a deviant sexual proclivity' with 'a morally destructive effect on the substance of society' justified the conviction imposed for serious

35 Morgan (n 4) 220-1.

36 L C Backer, 'Toleration, Suppression and the Public/Private Divide: "Homosexuals" through Military Eyes' (1999) 34(3) Tulsa Law Journal 537-54, 538.

37 L C Backer, 'Exposing the Perversions of Toleration: The Decriminalization of Private Sexual Conduct, the Model Penal Code, and the Oxymoron of Liberal Toleration' (1993) 45(5) Florida Law Review 755-802, 793.

38 Backer (n 36) 541; Backer (n 37) 789.

39 Before them, the $S$ cherer case also concerned freedom of expression but it was considered inadmissible by the Court due to technical reasons: Scherer $v$ Switzerland (n 14).

40 Baczkonski and Others v Poland App no 1543/06 48 EHRR 19, para 101; Alekseyev v Russia (n 16) para 110.

41 An almost identical ruling was rendered by the Court regarding similar circumstances in the subsequent Genderdoc-M case: Genderdoc-M v Moldova App no 9106/06 (ECHR 12 June 2012).

42 Baczkowski and Others v Poland (n 40) para 68, 100 and 101; Alekseyev v Russia (n 16) paras 86-8 and 109-10.

43 Baczkowski and Others $v$ Poland (n 40).

44 Alekeseyev $v$ Russia (n 16) para 84.

45 Vejdeland and Others $v$ Sweden App no 1813/07 (ECHR 9 February 2012). 
and prejudicial allegations since it could be seen as necessary in a democratic society for the protection of the reputation and rights of others. ${ }^{46}$

On the other hand, even though one's sexual orientation could be publicly expressed, the same publicity concerning someone else's sexual orientation could be considered insulting. In the year 2009, the Court decided the Porubova case, regarding the compatibility of a criminal conviction with freedom of expression. The applicant had been convicted of the publication of a newspaper article in which she referred to two Russian male politicians allegedly involved in both a love story and an embezzlement scandal. She was convicted on the grounds of insult and criminal libel solely for the reference to the gay love story.

The Court decided that the conviction imposed was a violation of freedom of expression since it caused an interference with her right that did not appear to be necessary in a democratic society. ${ }^{47}$ Nonetheless, the Court did not express any objections to the fact that under the criminal legislation of the state, the public reference to someone's homosexuality could be considered an insult that harmed his/her honour and dignity. ${ }^{48}$ The questions that remain are: should the understanding of same-sex sexuality as harmful to a person's honour and dignity be accepted by the Court? And what does it say about the value given by the Court to same-sex sexuality?

In any case, the Court's homosexual has finally abandoned its limited private legality, having made his/her appearance in the public sphere with the approval of the Court. She/he can now publicly demand his/her human rights and is protected from homophobic expressions. Nevertheless, same-sex sexuality still remains of inferior value. The public discussion of the Court's homosexual's sexuality is not a violation of his/her private life - as would be the discussion of heterosexuality - but it is an offence to his/her honour and dignity.

\section{The inferior value of homosexuality}

The following two binaries are aimed at analysing how the denial and concession of human rights by the Court have been used to construct its homosexual as the legal inferior counterpart of the heterosexual subject. The binaries will show that the outcome of the Court's discourse regarding same-sex sexuality is the confirmation of its homosexual as different from the heterosexual subject, the true subject of human rights law. In fact, the differential entitlement of rights has been used to create the otherness of the Court's homosexual.

\section{A. EQUAL/DIFFERENT}

As explained in section 2, the Court only contemplates two possible sexualities, which are not of equal value. The Court's case law has actually created its homosexual by building on a sexuality that was marked from the outset by the impossibility of fitting into the right(ful) side of the heterosexual/homosexual binary. The equal/different opposition is the most evident display of how the Court's homosexual is continually reshaped as unequal to the heterosexual subject. This binary is present every time the Court analyses a case under the prohibition of discrimination. When the Court justifies a differential treatment of individuals based on their sexual orientation, it is shaping the Court's homosexual as ontologically different from its heterosexual counterpart.

46 Vejdeland and Others $v$ Sweden (n 45) paras 8, 54 and 58-60.

47 Porubova v Russia App no 8237/03 (ECHR 8 October 2009), paras 50-1.

48 Ibid paras 27-8. 
According to the Court, discrimination means differential treatment which is detrimental to the enjoyment of human rights and lacks a reasonable and objective justification. This means that a performed difference is discriminatory when it does not pursue a legitimate aim, or when there is no reasonable proportionality between the means employed and the aim sought to be realised. ${ }^{49}$ However, since the Convention does not offer an autonomous protection from discrimination, the Court can only rule on discrimination in conjunction with the enjoyment of another enunciated right. ${ }^{50}$

Regarding differential treatment based on sexual orientation, the Court's case law affirms that very weighty reasons need to be offered to justify the distinction. ${ }^{51}$ In other words, sexuality is conceived as a category that should be relatively indifferent to the law. However, the similarity of sexual subjects does not mean their equality, since their difference is admitted when strong reasons justify it.

The Court has suggested the equality of the homosexual and heterosexual subjects, affirming that a difference based on sexual orientation is discriminatory in itself. ${ }^{52}$ In its own words, the Court stated that if the reasons advanced for a difference in treatment were based solely on the applicant's sexual orientation, this would amount to discrimination under the Convention'. ${ }^{3}$

Nevertheless, the Court later pulled back from this statement, accepting differential rights based on sexual orientation. The Court has highlighted that: 'there remain issues where no European consensus has been reached, such as granting permission to same-sex couples to adopt a child . . . and the right to marry, and the Court has confirmed the domestic authorities' wide margin of appreciation in respect of those issues'. ${ }^{4}$ This new statement of the Court was by no means surprising, since the Court tends to allow states a wide margin to determine domestic policy in cases lacking European consensus. ${ }^{55}$ However, it did mean that the Court was accepting distinctions based on sexual orientation, seven months after having stated for the first time that they were per se discriminatory.

The Court has had the opportunity to analyse the equality/difference binary, through the prohibition of discrimination, on many occasions. As discussed above, the Court considered the existence of a differential age of sexual consent to be discriminatory ${ }^{56}$ and the ban imposed on gay pride events. ${ }^{57}$ The Court has also found discriminatory certain

49 Salgueiro da Silva Mouta v Portugal App no 33290/96 31 EHRR 47, para 29; EB v France App no 43546/02 47 EHRR 21, para 91; Schalk and Kopf v Austria App no 30141/04 53 EHRR 20, para 96.

50 On the 'parasitic' character of the prohibition of discrimination in the Convention, see: Harris et al (n 2) 577-615.

51 Salgueiro da Silva Mouta v Portugal (n 49) para 36; Karner v Austria App no 40016/98 38 EHRR 24, para 37; Kozake $v$ Poland App no 13102/02 51 EHRR 16, para 92.

52 Professor Stychin has argued that, if sexual orientation is considered to be immutable, then distinction based on this characteristic should be considered to be unjustified since it is based in a characteristic beyond the individual's control: Stychin (n 18) 59.

53 Kozak v Poland (n 51) para 92. This idea has been already sketched by the Court in its ruling EB $v$ France, and has been reaffirmed by the Court in Genderdoc- $M v$ Moldova and $X$ and Others $v$ Austria: EB $v$ France (n 49) para 93; Genderdoc-M v Moldova (n 41) para 51; X and Others v Austria App no 19010/07 (ECHR [GC] 19 February 2013), para 99.

54 Alekseyev v Russia (n 16) para 83

55 On the dynamic relation between the doctrines of 'European consensus' and 'margin of appreciation', see: Harris et al (n 2) 8-14.

56 L and V v Austria (n 25); SL v Austria (n 25); BB v UK (n 25); Woditschka and Wilfling v Austria (n 25); Ladner v Austria (n 25); Wolfmeyer v Austria (n 25); HG and GB v Austria (n 25); RH v Austria (n 25).

57 Baczkowski and Others v Poland (n 40); Alekseyev v Russia (n 16). 
distinctions in the enjoyment of relationship rights, but not all of them, as will be discussed in the next section. ${ }^{58}$

Furthermore, strong support for equality between the heterosexual and the Court's homosexual can be found in the 2013 ruling on Eweida and Others. On that occasion, two of the applicants had been sanctioned by their employers for refusing to perform certain duties in favour of gays and lesbians, based on the claim that, according to their Christian beliefs homosexuality was sinful and contrary to God's law. The first applicant, a public official, refused to conduct civil partnership ceremonies; while the second applicant, a counsellor for a private company, refused to provide sexual counselling to same-sex couples. The Court decided that the sanctions imposed on the applicants and confirmed by the domestic courts had been justified measures for the protection of the homosexual against discrimination. ${ }^{59}$

Consequently, the Court validated the state's understanding that the homosexual was equal enough to the heterosexual not to be treated detrimentally by either public bodies or private companies due to his/her sexuality. And that held to be true even when the differential treatment was based in religious convictions about the ungodly character of the homosexual. In other words, the Court's homosexual was certainly not the same as the Bible's homosexual.

On the other hand, the six cases dealing with parental rights are the paradigmatic example of the shifting use of the equal/different binary in the Court's case law. The Salgueiro da Silva Mouta case was the first occasion on which the Court dealt with parental rights of gays and lesbians and it was the first time that the Court stated that sexual orientation was a prohibited category of discrimination. ${ }^{60}$ In its ruling, the Court decided that the award of parental responsibility for a child based on the sexual orientation of one of the parents was a violation of the prohibition of discrimination. ${ }^{61}$ Similarly, in the $J M$ case, the Court ruled that the differential assessment of child support payments based on the sexual orientation of the parent amounted to unlawful discrimination. ${ }^{62}$ Therefore, the Court decided that sexual orientation could not be used as a criterion to justify the award of parental custody, or a differential amount of child support.

Nevertheless, the relevance of sexual orientation for granting an adoption is a more controversial topic and the Court has dealt with it on different occasions. According to the Court, there are three types of adoption - individual adoption, second-parent adoption and joint adoption - which raise different kinds of concerns. ${ }^{63}$ In the first two cases, Frette and $E B$, the Court dealt with individual adoption. In Fretté, the Court decided that the sexual orientation of an individual could be a legitimate foundation to refuse authorisation to adopt. ${ }^{64}$ It took the Court almost six years to overturn this criterion, but in the EB case the Court decided that restricting the right to adopt based on the sexual orientation of the applicant was indeed discriminatory. ${ }^{65}$

58 While distinctions on the right to succeed to a partner's tenancy and the right to benefit from a partner's health insurance were considered to be discriminatory, the legal ban on same-sex marriage was understood to be an acceptable distinction: Karner v Austria (n 51); Kozak v Poland (n 51); PB and JS v Austria App no 18984/02 (ECHR 22 July 2010); Schalk and Kopf v Austria (n 49).

59 Eweida and Others $v$ UK App nos 48420/10; 59842/10; 51671/10; 36516/10 (ECHR 15 January 2013), paras 106 and 110 .

60 Salgueiro da Silva Mouta v Portugal (n 49) para 36.

61 Ibid paras 35-6.

$62 J M v U K$ App no 37060/06 53 EHRR 6, paras 55-8.

$63 X$ and Others v Austria (n 53) para 100.

64 Fretté v France App no 36515/97 38 EHRR 438, para 42.

65 EB $v$ France (n 49) para 96. 
The Court then dealt with the issue of second-parent adoptions in two subsequent cases, Gas and Dubois and $X$ and Others. First, in Gas and Dubois, the Court examined the French prohibition of second-parent adoption for same-sex couples. In that case, two women bound by civil partnership (pacte civil de solidarité (PACS)) had had a child through assisted reproduction, but only the biological mother was recognised as parent of the child. The domestic legislation only allowed married couples to share parental responsibility through second-parent adoption, denying unmarried couples the same right. The Court found the legislation to be compatible with the Convention, since it understood that both same-sex and different-sex unmarried couples were treated equally. ${ }^{66}$

Nonetheless, the rationale of the Court's ruling minimised the fact that, while unmarried different-sex couples could obtain shared parental responsibility by getting married, this possibility was legally forbidden to same-sex couples. Therefore, the comparison made by the Court masqueraded a concrete distinction as equality. ${ }^{67}$ The Court constructed the single homosexual as equal to the single heterosexual, at the same time that it constructed them both as different from the married heterosexual. However, this construction of single individuals as different from married ones becomes especially relevant when the laws prohibit homosexual individuals from marrying. Indeed, the fact that the homosexual could only be a 'single' homosexual meant that she/he would always remain different from the heterosexual.

The issue of second-parent adoption was revisited by the Court in the $X$ and Others case. The situation this time was different, since the legislation under analysis allowed both married and single heterosexuals to adopt the children of their partners, while this type of adoption was forbidden to the single homosexual, who was also legally unable to marry his/her partner. The Court decided that it was discriminatory to deny second-parent adoption to the homosexual, as long as this was allowed for the single heterosexual. ${ }^{68}$

Nevertheless, the Court again found that it was not discriminatory to allow secondparent adoption to the married heterosexual, but to deny both marriage and second-parent adoption to the homosexual. ${ }^{69}$ Consequently, the Court confirmed that its homosexual should be formally conceived as equal to the single heterosexual. However, this equality was apparent rather than real, since the single heterosexual was allowed to marry and become a married heterosexual, an individual entitled to rights denied to the Court's homosexual.

Lastly, the issue of joint adoption by same-sex couples has not yet been considered by the Court within an actual case. Nonetheless, the Court has rendered obiter dictum a clear opinion on the matter. In the Alekseyev ruling, the Court stated that the issue of joint adoption by same-sex couples lacked European consensus, gratuitously leaving the states a wide margin of appreciation on the topic. ${ }^{70}$

Therefore, according to the Court, it is discriminatory to forbid a single person to adopt based on the sexual orientation of the prospective parent, but prohibiting that same adoption based on the sexual orientation of both prospective parents is allowed. In other words, the Court has affirmed that heterosexual and homosexual parents should be

66 Gas and Dubois v France App no 25951/07 (ECHR 15 March 2012), para 73.

67 In fact, Johnson has expressed the view that the Court's refusal to compare same-sex couples in a PACS with married couples when same-sex marriage is legally forbidden can appear obtuse or even perverse: P Johnson, 'Adoption, Homosexuality and the European Convention on Human Rights: Gas and Dubois v France' (2012) 75(6) Modern Law Review 1123-49, 1147.

$68 X$ and Others $v$ Austria (n 53) para 153.

69 Ibid para 110.

70 Alekseyev v Russia (n 16) para 83. 
considered both different from and equal to each other: they are sufficiently equal to allow gays and lesbians to adopt as single parents; and they are different enough to refuse their applications for adoption as couples.

In conclusion, the Court conceives its homosexual as unequal to the heterosexual subject and the acceptance of differential treatment in the protection of human rights is the means by which the existence of a difference is materialised. While the differential treatment is presented as the logical corollary of the ontological difference between the Court's homosexual and the heterosexual subject, it is actually through the approved differences that the Court constructs its homosexual as the necessary inferior counterpart to the heterosexual subject of human rights. Even though the issues in which the differential treatments are admitted have a tendency to get narrower, their existence is required, since their complete absence will jeopardise the differential character of the Court's homosexual and the privileged status of the heterosexual subject. Consequently, the existence of legal differences, even contradictory ones, seems to be needed by the Court's case law.

\section{B. COUPLE/UNCOUPLE}

The couple/uncouple binary draws attention to the manner in which the Court has decided that some couples are entitled to the enjoyment of all rights that the status grants, while others are not recognised as true couples. Between the years 2001 and 2010, the Court decided a series of nine cases that established that only different-sex couples are to be considered real ones. The Court has recognised true couples and 'uncoupled' false ones in cases that concerned: the right to succeed to a tenancy; the right to be exempted from inheritance tax; the right to benefit from a partner's health insurance; the right to a survivor's pension or payment; and the right to marry.

The Court dealt with three cases that concerned whether an individual was entitled to succeed to the tenancy contract of a deceased same-sex partner, or if such a right could be limited by the state to different-sex partners. On two occasions, the Karner and the Kozak cases, the Court stated that it was discriminatory to exclude surviving same-sex partners from the right to continuation of a tenancy. ${ }^{71}$ The Court affirmed that differential treatment based on sexual orientation required very serious reasons by way of justification, however, no compelling arguments had been offered to justify the exclusion of same-sex partners from the right to continue a tenancy. ${ }^{72}$

On the other hand, in the Korelc case, the Court found no discriminatory treatment when the continuation of a tenancy was refused. The judgment of the Court did not contradict its previous rulings, since it still rejected the distinction between same-sex and different-sex couples. However, the Court approved a differential treatment based on the applicant not being in a long-term sexual relationship with the deceased tenant, but in a relationship based on economic dependency. ${ }^{73}$ Therefore, regarding the continuation of a tenancy, the Court has not ruled out that same-sex couples may be 'true couples': the Court's homosexual can be in a true couple, as long it is not just based on economic factors.

Similarly, in the $P B$ and JS case, the Court found that an accident and sickness insurance policy that only covered different-sex partners was incompatible with the prohibition on discrimination. ${ }^{74}$ With explicit reference to the Karner ruling, the Court decided that there

71 Karnerv Austria (n 51) paras 42-3; Kozak v Poland (n 51) para 99.

72 Karner v Austria (n 51), paras 37 and 41; Kozak v Poland (n 51) paras 92 and 99.

73 Korelc v Slovenia App no 28456/03 (ECHR 12 May 2009), para 88.

$74 P B$ and JS v Austria (n 58) paras 42-4. 
were no reasons justifying a distinction between same-sex and different-sex couples. ${ }^{75}$ Once again, the Court's homosexual could be part of a real couple in terms of entitlement to a partner's health insurance.

By contrast, the subject of inheritance tax has been used by the Court to draw the line between being coupled or uncoupled. In the Courten case, the Court analysed whether the rejection of a tax exemption for the survivor of a same-sex cohabiting couple, who were legally unable to marry, was discriminatory on the grounds of sexual orientation. The Court rejected the application, finding that the absence of a legally binding agreement between the partners made their relationship fundamentally different to that of a married couple or a civil partnership. The Court also refused to find a violation of the applicant's rights due to the lack of the legal possibility to enter into such a relationship. ${ }^{76}$ In other words, only true couples were allowed tax exemptions and same-sex couples were not coupled enough.

Another criterion distinguishing real from unreal couples is the right to a survivor's pension. The Court has rejected all three cases in which it was argued that the refusal to grant a pension or a payment to the survivor of a same-sex couple amounted to discrimination on the grounds of sexual orientation. When the right to a pension was at stake, the Court decided to uncouple same-sex partners.

The first of these decisions was adopted in the year 2001 in Mata Estever, in which the Court stated that same-sex couples did not fall within the scope of the right to respect for family life. ${ }^{77}$ In fact, the Court understood that states, through the exclusion of same-sex couples from the rights to a survivor's pension, were actually protecting 'the family based on marriage bonds'. ${ }^{78}$ The second of these rulings was in the $M W$ case, in which the Court basically reiterated the criteria used in Courten. The only difference was that this time the Court rejected a claim for a bereavement payment from the survivor of a same-sex cohabiting couple instead of a tax exemption. ${ }^{79}$ Lastly, in the Manenc case, the Court dealt with the refusal of a survivor's pension despite the actual existence of a PACS between the couple. With explicit reference to Mata Estevez, the Court affirmed that still in the year 2010 states were allowed to differentiate between the legal benefits conferred upon same-sex and different-sex couples. ${ }^{80}$

With these judgments, the Court started constructing an unstable border between real and unreal couples. The Court's homosexual is recognised as part of a true couple in certain situations, to be later uncoupled by the Court in seemingly similar circumstances. In fact, the incoherent uncoupling effect that the Court has attributed to certain rights has already been highlighted by some of the judges of the Court. Only a week after the Court used the Mata Estevez case as a precedent for the Manenc ruling, three of the judges stated that Mata Estevez was not only incompatible with the Convention in the year 2010 but that it was already wrong at the moment of its adoption. ${ }^{81}$ Consequently, the Court's homosexual seems to alternate uneasily between both sides of the couple/uncouple binary, while the unstable limit of the dichotomy is being re-inscribed by the Court.

Only one strict dividing line between real and unreal couples seems to exist: marriage. In the Schalk and Kopf case, the Court decided that the Convention did not grant everyone

$75 P B$ and JS $v$ Austria (n 58) para 44.

76 Courten v UK App no 4479/06 (ECHR 4 November 2008), para 65.

77 Mata Estevezy Spain App no 56501/00 (ECHR 10 May 2001).

78 Ibid.

$79 M W v$ UK App no 11313/02 (ECHR 23 June 2009).

80 Manenc v France App no 66686/09 (ECHR 21 September 2010).

$81 J M v U K$ (n 62), concurring opinion of Judges Garlicki, Hirvelä and Vučinić. 
the right to marry, since states were free to grant access to such a right solely to differentsex couples. ${ }^{82}$ The Court also affirmed that the rights conferred on same-sex registered partnerships might differ from those conferred on married couples, without amounting to discriminatory treatment. ${ }^{83}$

The Court decided to formulate the case as a dilemma involving two of its historical opinions: should it keep the understanding of marriage as the legal union of a heterosexual man and a heterosexual woman? Or, should it continue to interpret the Convention in the light of present-day conditions, opening marriage to the Court's homosexual? In other words, the Court understood that a choice was needed between safeguarding the heterosexual privilege and preserving the progressive interpretation of the Convention and picked the first option.

The Court abandoned its extensive case law concerning the interpretation of the Convention in the light of present-day conditions. ${ }^{84}$ It affirmed that: 'regard must be had to the historical context in which the Convention was adopted. In the 1950s marriage was clearly understood in the traditional sense of being a union between partners of different sex'. ${ }^{85}$ Therefore, in order to draw a specific line between real and unreal couples, the Court decided to travel 60 years back in time.

The Court's ruling seems to be consistent with the homosexual that has been constructed in the case law. This judgment reinforced the inferior character of the Court's homosexual through the denial of rights. However, it also meant that the Court missed an opportunity to strengthen the traditional institution of marriage. Allowing the sexuality of the Court's homosexual to enter this institution would have certainly reinforced the idea of marriage as the true model for legitimate sexuality. By contrast, through the exclusion of the homosexual, the Court validated the idea that legitimate sexuality exists both inside and outside the institution of marriage.

Furthermore, seemingly as a trade-off, the Court decided to state that, even though same-sex couples could not enjoy the right to marry, they could at least be considered included within the notion of 'family'. The Court said that a cohabiting same-sex couple living in a stable partnership should be recognised as a 'family', just as the relationship of a different-sex couple in the same situation would be. ${ }^{86}$ This particular statement was also reiterated the very next month in the $P B$ and $J S$ ruling. ${ }^{87}$ Nonetheless, it is still not clear whether this statement will truly have any significant legal effects, or if the legal content of 'family' has actually been emptied by the Court. In fact, less than two months after becoming 'families', same-sex couples were again denied the enjoyment of the right to a survivor's pension, in the Manenc case.

82 Schalk and Kopf v Austria (n 49) para 108.

83 Ibid paras 109-10. However, this statement might not be compatible with the Burden judgment issued by the Grand Chamber, in which a clear analogy is made between married couples and those in a registered civil partnership: Burden v UK App no 13378/05 (ECHR [GC] 29 April 2008), para 65.

84 Fretté v France (n 64) para 34; EB v France (n 49) para 46.

85 Schalk and Kopf $v$ Austria (n 49) para 56.

86 Ibid para 94

87 PB and JS v Austria (n 58) paras 28-30. 
In conclusion, same-sex couples can be placed on any side of the unstable couple/uncouple binary, depending on the circumstances. ${ }^{88}$ Even though the Court has recently allowed its homosexual to be a part of a legal family, same-sex couples will still be uncoupled through the denial of the right to marry, survivors' pensions and tax exemptions. Consequently, only couples formed by two heterosexual subjects are necessarily recognised as real, since the Court grants only them the full enjoyment of all human rights.

\section{A possible way forward? (Self/Other)}

The developing case law of the Court has shaped the lesser value of its homosexual through the denial of an equal enjoyment of human rights. As stated at the outset, the Court's homosexual has been constructed following the exclusionary process that only allowed $\mathrm{him} /$ her to become the Other, an inferior counterpart of the heterosexual subject. ${ }^{89}$

The Court's homosexual, as the Other, is needed for the reinforcement of the heterosexual individual as the norm(al). The heterosexual is the ideal person entitled to the human rights recognised by the Convention, while the homosexual Other deserves a treatment that is similar, but is not the same. Most rights should be graciously granted to the Court's homosexual, but the majoritarian heterosexual consensus will decide the limit to such concessions. As long as his/her character of Other is needed for the delimitation of the human rights subject, the Court's homosexual will never be able to become a true legal subject.

In fact, the Court ensured that the foundational text of the system remains heterosexual when it affirmed that the right to marry was conceived that way. ${ }^{90}$ With that ruling, the Court made an invaluable contribution to heterosexual privilege. It confirmed that only the heterosexual is the true subject of human rights and the Court's homosexual can only be conceived as its inferior opposite counterpart. The Court strategically presented itself as forced by its constitutional treaty to recognise the heterosexuality of human rights, placing the heterosexuality of human rights as a topic beyond any possible discussion.

Currently, the Court supports contradictory statements, which can only be coherently held together by the understanding that the Court's homosexual is the equal that reassures the uniqueness of the heterosexual. It is as equal as the Other can be. It deserves the legal equality that allows the Court to approve differential treatment and only in certain circumstances provide true sexual indifference.

The Court held to be true that a difference based on sexual orientation was discriminatory in itself, ${ }^{91}$ while at the same time it allowed a wide margin of appreciation for the states to adopt differential treatment based on sexual orientation. ${ }^{92}$ In 40 rulings, the Court has shown a (lack of) legal coherence that allows affirming that the Court's

88 The uneasy limit separating the couple/uncouple binary reappeared recently in the Vallianatos and Others case against Greece. In this ruling, the Court analysed the introduction of civil partnerships in Greece and decided that, because this legal institution was restricted to different-sex couples, it was discriminatory against samesex couples. However, before reaching this decision, the Court felt the need to clarify that it was not ruling that states were under the obligation to provide for a form of legal recognition for same-sex couples, but it was only stating that when a state decides to offer couples the possibility to enter into a civil partnership it cannot limit this right to different-sex couples: Vallianatos and Others v Greece App nos 29381/09; 32684/09 (ECHR [GC] 7 November 2013), paras 75 and 90-2.

89 Butler (n 7) xiii.

90 Schalk and Kopf $v$ Austria (n 49).

91 Kozak v Poland (n 51) para 92; EB v France (n 49) para 93; Genderdoc-M v Moldova (n 41) para 51; X and Others v Austria (n 53) para 99.

92 Alekseyev v Russia (n 16) para 83. 
homosexual is both an equal who should not be treated differently and the Other whom states can differentiate from the heterosexual subject.

What the Court has so far not shown its homosexual is enough indifference for his/her sexuality to become as legally irrelevant as the sexual orientation of the heterosexual subject. Since the law has a normalising effect on the construction of sexual identities, ${ }^{93}$ making homosexuality legally irrelevant will subtract the binary sexualised individual from this disciplinary regime. In other words, legal indifference to individuals' sexuality would put a stop to the regulatory power exercised by the Court on the performative character of sexual identities. If, in the future, the Court decides to let its homosexual become an authentic subject of human rights, the homosexual's sexual orientation will have to become irrelevant. That day, the homosexual Other will become the 'Self', binaries will be transcended and the homosexual subject will necessarily disappear from the Court's case law.

\section{Conclusion}

The Court's homosexual is over 30 years old and his/her presence in the Court's case law will probably continue in the years to come. The analysis performed in this article has shown how the Court has exercised the regulatory power of the law to construct its homosexual subject. Starting from a categorical conception of sexuality and through the concession and denial of human rights, the Court has created its homosexual as the needed inferior counterpart of the heterosexual subject.

It is true that the Court's homosexual has seen his/her original status of private subject modified, having gained the right to step outside the closet into the public sphere. However, this alleged improvement has been coupled with different restrictions on the enjoyment of rights, as necessary measures that allow the re-affirming of the privileged status of the heterosexual subject. In particular, the Court's decision to (hetero)sexualise the Convention has secured the heterosexual subject as the only one entitled to the full enjoyment of human rights.

Nonetheless, the inferior legal status granted by the Court to its homosexual could easily be modified by amendment of the Court's case law. ${ }^{94}$ A jurisprudence that enforces indifference towards the sexual orientation of the human rights subject will necessarily cause the disappearance of both the Court's homosexual and its privileged counterpart. In fact, a strategy based on indifference can help avoid the reinforcement of the fixed sexual identities questioned by queer theory.

This potential disappearance of the Court's homosexual would contribute to reducing the regulatory power of the Court over individuals' sexual bodies, but it would certainly not exhaust the applicability of queer theory to the analysis of the Court's case law. In fact, human rights law, as a discourse that holds a claim to universality in the entitlement to rights, could take further advantage of the ability of queer theory to continuously interrogate the process of exclusion.

93 Morgan (n 4) 217-18; Zanghellini (n 6) 6.

94 In this sense this work distances itself from the position adopted by Michele Grigolo concerning the need to delete Article 12. Grigolo (n 3) 1042. As stated through the analysis of the Schalk and Kopf case (n 49), the wording of Article 12 could be easily re-interpreted by the Court to include same-sex marriage. In fact, the Article could be re-interpreted in so many different ways so as to read, if desired, different-sex marriage, samesex marriage, or group marriage. Moreover, since the Article does not impose a definition of marriage, this institution could be recreated within the Convention in any imaginable way. 